\title{
Identifikasi Kesadaran Diri pada Anak di TK Negeri Pembina Pohuwato
}

\author{
Nurmala Ganil, Tuti Wantu, Pupung Puspa Ardini \\ Universitas Negeri Gorontalo \\ Pupungpuspa@ung.ac.id
}

\begin{tabular}{l}
\hline Info Artikel \\
\hline Sejarah Artikel: \\
Diterima (Desember) (2019) \\
Disetujui (Januari) (2019) \\
Dipublikasikan (Januari) \\
(2019) \\
\hline Keywords: \\
Kesadaran diri, Anak \\
Usia Dini, Taman \\
Kanak-Kanak. \\
\hline
\end{tabular}

\begin{abstract}
Abstrak
Tujuan penelitian ini adalah untuk mengidentifikasi kesadaran diri pada anak kelompok B. Metode penelitian yang digunakan yaitu metode deskriptif dengan jenis penelitian Kualitatif. Data dalam penelitian ini dapat di peroleh langsung dari informan sekolah yaitu orang-orang yang terlibat langsung dalam sekolah seperti kepala sekolah dan guru-guru dan orang tua. Penelitian ini menggunakan teknik pengumpulan data melalui observasi, wawancara, dan dokumentasi. Dari hasil penelitian diketahui bahwa identifikasi kesadaran diri pada anak Kelompok B TK Negeri Pembina Kecamatan Paguat Kabupaten Pohuwato dapat di identifikasikan. Diantaranya: a). anak-anak sudah mampu mengetahui kesadaran emosi dan menyadari perasaannya. b). Penilaian diri atau kemampuan memandang dirinya sendiri, dari 18 anak terdapat 3 anak yang belum mampu mengetahui nama panjangnya. c). sedangkan untuk percaya diri tampil di depan kelas dan menyatakan pendapatnya, anak-anak sudah mampu melakukannya bahkan saling berebut untuk maju di depan kelas.
\end{abstract}

\begin{abstract}
The purpose of this study is to research self-awareness in children $B$. The research method used is descriptive method with qualitative research type. The data in this study can be obtained directly from school informants namely people who are directly involved in the school such as school principals and teachers and parents. This study uses data collection techniques through observation, interviews, and documentation. From the results of research that is known about the awareness in Group B TK Pembina Negeri Paguat District Pohuwato Regency can be identified. Among them: a). children are able to understand awareness and understand their feelings. b). Self-assessment or the ability to see themselves, of 18 children 3 who have not been able to understand the full name. c). Meanwhile, to confidently appear in front of the class and express their opinions, the children can ask for help to scramble to get ahead of the class.
\end{abstract}

(C) 2019 Nurmala Ganil, Tuti Wantu, Puung Puspa Ardini 


\section{Pendahuluan}

Melihat kenyataan dilapangan, khusunya di TK Negeri Pembina Kecamatan PaguatKab. Pohuwato, berdasarkan pengamatan dan diskusi dengan guru kelas yaitu pada umumnya anak masih memiliki kesadaran diri yang masih rendah. Hal tersebut peneliti dapatkan dalam aktifitas mengajar di TK Negeri Pembina kecamatan paguat kab.pohuwato. Dari 18 anak masih ada beberapa anak yang tidak mau bekerja sama dengan temannya dalam kegiatan bermain berkelompok. Mereka lebih memilih melakukan kegitannya sendiri misalnya, dalam kegiatan menyusun balok ada anak yang tidak mau melakukannya secara bersamaan atau bergilirian melainkan akan tersebut mengerjakannya sendiri tanpa adanya kerja sama sesama teman kelompoknya anak jarang sekali bergaul dengan temannya dan berinteraksi ataupun berkomunikasi sesama teman sebayanya. Selain itu, ada pula anak yang tidak mau berbagi sesama teman. Misalnya, meminjamkan permainan pada teman atau benda yang lainnya.

Melihat permasalahan diatas, dari observasi awal bulan agustus maka peneliti tertarik untuk melakukan sebuah penelitian dengan formulasi judul "identifikasi kesadaran diri anak kelompok $\mathrm{B}$ di Tk Negeri Pembina kecamatan paguat kab.pohuwato, Sehingga guru dan orang tua mengetahui dan mampu mengembangkan perkembangan sosial bagi anak.

\section{Metode Penelitian}

Penelitian ini dilaksanakan di TK Pembina Kecamatan Paguaat Kabupaten Pohuwato. Alasan memilih lokasi ini karena peneliti memiliki pengalaman mengajar dilokasi tersebut. Selain itu TK Pembina Kecamatan Paguat pada kesadaran diri anak masih tergolong rendah. Hal ini terlihat pada anak yang tidak mau bekerja sama dengan teman dalam kelompoknya misalnya dalam melakukan kegiatan menyusun balok, anak tersebut lebih menyukai melakukan kegiatannya sendiri dan tidak mau bergaul atau jarang melakukan komunikasi dengan teman ataupun gurunya dan juga anak yang tidak berbagi sesama teman misalnya meminjamkan permainan pada teman atau benda yang lainnya. Sehingga peneliti tertarik untuk mendeskripsikan identifikasi kesadaran diri anak kelompok B TK Pembina Kecamatan Paguat Kabupaten Pohuwato. 
Proses analisis data dilakukan untuk mengidentifikaasi kesadaran diri anak Kelompok B TK Negeri Pembina Kecamatan Paguat Kabupaten Pohuwato. Proses analisis data dilakukan dengan menggunakan pendekatan deskriptif kualitatif, dimana hasil penelitian ini mendeskripsikan atau menggambarkan keadaan berdasarkan yang terjadi dilapangan.

Tahap Perencanaan

Tahap perencanaan dilakukan dengan cara 1) Menentukan kelas untuk dijadikan subjek penelitian dan menetapkan waktu penelitian, 2) Mendiskusikan dan menyusun pedoman observasi dan wawancara yang akan digunakan untuk mengidentifikasi kesadaran diri anak.

Tahap Pelaksanaan

Melakukan pengamatan melalui teknik observasi dan wawancara di tk negeri pembina kecamatan paguat kabupaten pohuwato untuk memperoleh data yang lebih jelas dan akurat sehingga dapat di analisis dengan berbagai metode untuk memperoleh hasil yang lebih valid

\section{Hasil Penelitian dan Diskusi}

\section{Hasil}

Kesadaran diri merupakan dasar kecerdasan emosional. Kemampuan untuk memantau emosi dari waktu ke waktu merupakan hal penting bagi wawasan psikologi dan pemahaman diri. Seseorang yang mempunyai kecerdasan emosi akan berusaha menyadari emosinya ketika emosi itu menguasai dirinya.

Berdasarkan hasil temuan yang ada di TK Negeri Pembina Kecamatan Paguat Kabupaten Pohuwato Kelompok B1 menunjukan bahwa 1) Kesadaran Emosi. Dari hasil pengamatan awal di TK Negeri Pembina Kecamatan Paguat diketahui bahwa kemampuan untuk anak mengetahui emosinya anak-anak sudah mampu mengetahui bahwa dia sedang marah,sedih, senang. Oleh sebab itu ada anak yang memang tidak suka di ganggu oleh temannya berarti anak itu kemarahannya Nampak pada wajahnya bahwa dia sedang marah. 2) Penilain diri. Dari hasil pengamatan awal di TK Negeri Pembina Kecamatan Paguat diketahui bahwa kemampuan memandang dirinya sendiri anak-anak sudah dapat mengenal dirinya saat bercermin, mengenal jenis kelamin, 
umurnya dan nama panjangnya. karena pada semester 1 itu masuk pada tema diri sendiri, tetapi ada 3 orang anak yang kurang mampu mengenal nama panjangnya. dikatakan kurang mampu karena untuk mengenal nama panjanganya masih di bantu oleh guru kelas yang ada di B1.

\section{Diskusi}

Kesadaran Emosi

Dari hasil pengamatan awal di TK Negeri Pembina Kecamatan Paguat diketahui bahwa kemampuan untuk anak mengetahui emosinya anak-anak sudah mampu mengetahui bahwa dia sedang marah,sedih, senang. Oleh sebab itu ada anak yang memang tidak suka di ganggu oleh temannya berarti anak itu kemarahannya Nampak pada wajahnya bahwa dia sedang marah. Sejalan dengan hasil wawancara menunjukkan bahwa Ada anak yang bawaan dari rumah sementara proses pembelajaran anak itu tidak fokus untuk belajar mendengarkan guru yang sedang menjelaskan di depan kelas. Tetapi guru selalu memberikan motivasi dan mendekati anak-anak menayakan penyebab dari kesehiannya yang tadi. Dengan memberikan motivasi maka akan memberikan suatu dorongan agar anak fokus untuk belajar. Hal ini dibuktikan pula oleh penelitian Mendatu (2010), bahwa kesadaran diri adalah keadaan dimana seseorang bisa memahami dirinya sendiri dengan setepat- tepatnya. Seseorang disebut memiliki kesadaran diri jika seseorang tersebut memahami emosi dan mood yang sedang dirasakan, kritis terhadap informan mengenai dirinya sendiri, dan sadar tentang dirinya yang nyata.

Penilain diri

Dari hasil pengamatan awal di TK Negeri Pembina Kecamatan Paguat diketahui bahwa kemampuan memandang dirinya sendiri anak-anak sudah dapat mengenal dirinya saat bercermin, mengenal jenis kelamin, umurnya dan nama panjangnya. karena pada semester 1 itu masuk pada tema diri sendiri, tetapi ada 3 orang anak yang kurang mampu mengenal nama panjangnya. dikatakan kurang mampu karena untuk mengenal nama panjanganya masih di bantu oleh guru kelas yang ada di B1. Maslow dalam teorinya Humasnistik mengemukakan tentang kesadaran diri adalah menegrti dan memahami siapa diri kita, bagaimana menjadi diri kita sendiri, apa potensi yang kita 
miliki, gaya apa yang anda miliki, apa langkah,langkah yang anda ambil, apa yang dirasakan, nilai-nilai apa yang kita miliki dan yakin, kearah mana perkembangan kita akan menuju.

Percaya diri

Sejalan dengan hasil pengamatan awal di TK Negeri Pembina Kecamatan Paguat diketahui bahwa anak-anak yang ada di kelas B1 sangat percaya diri untuk tampil di depan kelas dan mampu menyatakan pendapat mereka tentang apa yang mereka inginkan dan apa yang mereka tidak sukai. Anak-anak super hebat pada kegiatan yang harus di kerjakan di depan kelas bahkan mereka berebut. Hal ini di dukung penelitian dari Boyatzis (1999), percaya diri yaitu keberanian datang dari kepastian tentang kemampuan, nilai-nilai adan tujuan. Seseorang dengan kecakapan ini ditandai dengan berani tampil dengan keyakinan diri atau berani menyatakan "keberadaannya" berani menyuarakan pandangan yang tidak popular dan bersedia berkorban demi kebenaran, mampu membuat keputusan yang baik kendati dalam keadaan tidak pasti dan tertekan.

\section{Simpulan}

Berdasarkan hasil penelitian dan pembahasan dapat disimpulkan bahwa indentifikasi kesadaran diri pada anak kelompok B di TK Negeri Pembina Kecamatan Paguat Kabupaten Pohuwato seacara umum yaitu : a) anak mampu mengetahui emosi dan menyadari perasaannya anak-anak yang berjumlah 18 orang mereka dapat mengenal emosi mereka. b) penilaian diri atau kemampuan memandang dirinya sendiri dari 18 anak 3 orang anak yang belum mampu mengetahui nama panjangnya. c) sedangkan yang berani tampil di depan kelas dan menyatakan pendapatnya 18 anak sudah mampu melakukannya bahkan berebutan untuk maju di depan kelas dan menyatakan pendapat mereka. Pada hasil wawancara guru dan orang tua telah didapatkan bahwa anak sudah mengenal bagaimana emosi tersebut, di buktikan pada dokumentasi di atas.

\section{Daftar Pustaka}

Auzoult, L and Hardy-Massard,S (2014) Desirability Associated with the Expression of Self, Consciousness In a French Population. Swiss Journal of Psychology, 73 (3) 183-188.

Andren. U (2012). Self-awereness and Self knowledge in Professions : Something

Anwar.2004, Pendidikan Kecakapan Hidup (Life skills education) Konsep \& Aplikasi. Bandung : Alfabeta. 
Anthony Dio Martin, Emotional Quality Management, Refleksi, Revisi dan Revelitalisas, Hidup Melalui Kekuatan Emosi. HIm 193

Baron, A Robbert \& Donn Byne, Psikologi Social Jilid I, Jakarta : Erlangga 2005

Brown, Duane \& Srebalus D.J . 1988. An Introduction to the Counseling Profession. Boston: Allyn \& Bacon.

Budiraharjo, Paulus. Jogjakarta 2002. Mengenal Kepribadian Mutakhir

Carol, S Catron. 1999. Early Childhood Curriculum second Education A Creative Play Model. Prentice- Hall,inc.

Danial Goleman, Emotional Intelligence Why It Can More Than IQ hIm 42

Duval, T.S \& Silvia, P.J (2002) Self- Awareness, Probability Improvoment, \& social Psyclogy 82, (1), 49-61.

Danial Goleman, Emotional Inteligence Why it Can Matter More Than IQ. Batam Books. New York, 1996, hlm 58

Danial Goleman, Emotional Intelegence Why it Can More Than IQ. hlm 64

Danial Goleman, Emotional Intelegence Why it Can More Than IQ. Hlm 65 